RESUME

\title{
Pengenalan Sistem Komputer
}

\author{
RAMA DEWANTORO
}

195120040

FAKULTAS KOMPUTER

$\underline{\text { Ramadewantoro.student@umitra.ac.id }}$

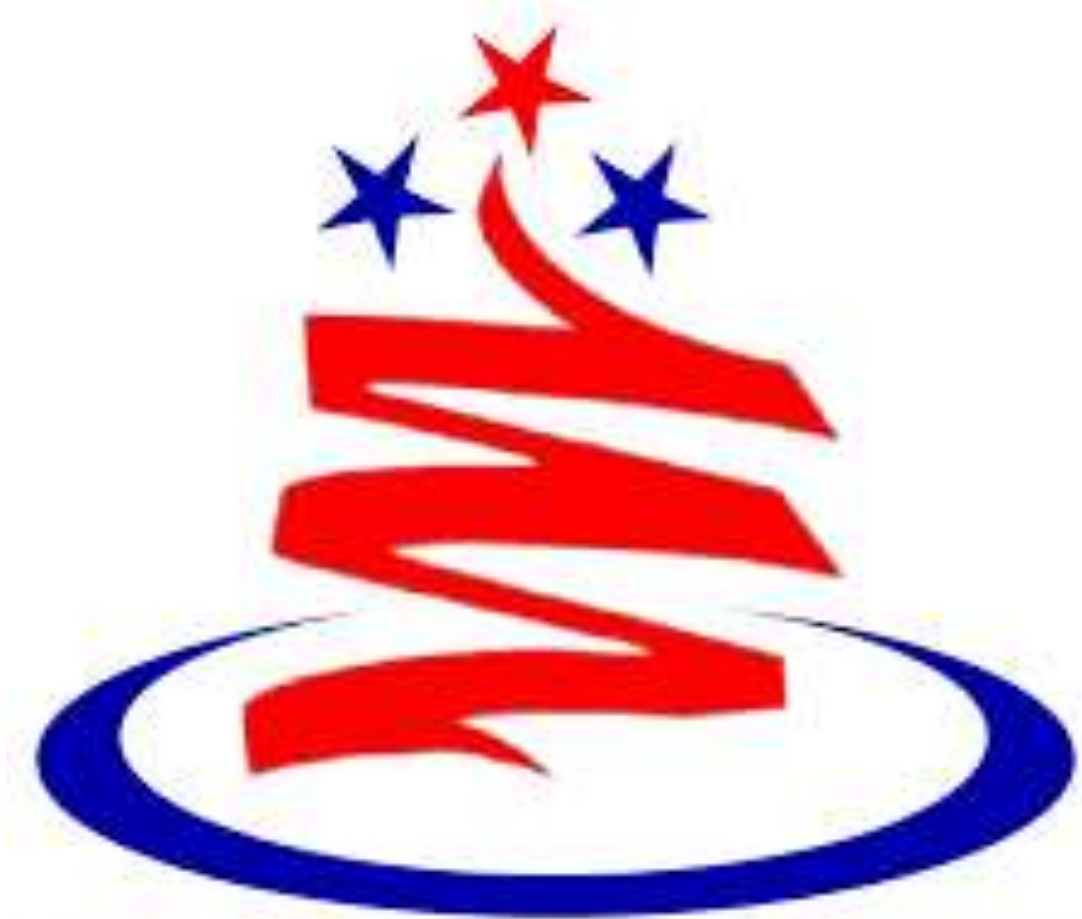

UnIVERSITAS MITRA INDONESIR 


\section{PENGENALAN SISTEH KOMPUTER}

\section{A. PENGENALAN KOMPUTER}

1. Pengertian Komputer Penqqunaan komputer untuk berbagai kegiatan semakin tidak terelakan. Semua bidang dan sektor boleh dikatakan sudah melakukan komputerisasi dalam menunjanq aktifitasnya. Mulai dari perusahaan dan industri denqan aktifitas yang sangat kompleks dan karyawan yang jumlahnya ribuan, sampai kerumah tanqga, sudah dijangkau oleh komputer. Komputer untuk berbagai keperluan sudah tampak digunakan dimana-mana.

Komputer : merupakan sekumpulan rangkaian mesin elektronik yang bekerja bersama-sama dan dapat melakukan proses data / rangkaian pekerjaan secara otcmatis melalui perintah atau instruksi yang dibuat dalam suatu program.

2. Jenis Komputer Jenis komputer ini dapat diklasifikasikan sebagai berikut:

a. Menurut jenis data yang diolah

1). Komputer Digital, yaitu jenis komputer yang dibuat untuk mengolah data kuantitatif berupa angka-angka atau data-data yang bisa ditransfer menjadi data kuantitatif, baik berupa huruf tanda baca dan lain sebagainya.

2). Komputer Rnalog; jenis komputer yang digunakan untuk mengolah data-data kualitatif, seperti pengukuran temperatur, voltase listrik dan lain sebagainya.

3). Komputer Hybrid, yaitu jenis komputer yang dibuat untuk mengolah data baik kuantitatif maupun kualitatif. Pada komputer jenis ini, data yang akan diolah berbentuk kualitatif dengan keluaran berbentuk kuantitatif, atau sebaliknya. Contoh penggunaan kornputer ini adalah pada bidang robotika. 
B. Menurut bidang masalah

1). Komputer khusus, yang dibuat untuk tujuan tertentu dan spesifik. Misalnya komputer yang dirancang khusus untuk kedokteran, militer dan lain sqbagainya.

2). Komputer umum, kebalikan dari komputer khusus, seperti komputer pribadi/perorangan I Personal Computer / PC 1 yang dapat digunakan untuk bermacam-macam keperluan.

C . Menurut kemampuan

Pengelompokkan komputer menurut kemampuan ini merupakan suatu ha1 yang sangat relatif sekali. Pada dasarnya pengertian kemampuan yang dimaksud disini adalah kemampuan dari 'otak" komputer un tuk menampung data/instruksi. Tempat penampungan ini disebut memori/storage. Berapa banyak instruksi yang dapat ditampung oleh suatu komputer' tergantung kepada berapa besar memori/storage dari otak komputer tersebut.

Berdasarkan besarnya memori ini komputer biasanya digolongkan atas komputer dengan skala:

1) Kecil, dengan memory dibawah $4 \mathrm{Mb}$.

2) Menenqah, berkisar antara $4-8 \mathrm{Mb}$.

3) Eesar, dengan memory diatas $8 \mathrm{Mb}$.

\section{B. SISTEM KOMPUTER}

1. Perangkat Keras (Hardware)

Seperti sudah disinggung sebelumnya, Hardware merupakan sekumpulan mesin elektronik yang dapat juga dikatakan sebagai peralatan komputer itu sendiri. Dalam istilah Indonesia sering juga dinamakan sebagai perangkat keras komputer . Kumpulan peranqkat ini berada dalam suatu, jaringan kerja yang dinama kan sistem. 
Analoqi dari proses ini pada sistem komputer secara garis besar dapat dibuat sebagai unit-unit yang akan:

- membaca'data

- mengolah data yang sudah dibaca

- mengeluarkan hasil pengolahan

Bagian inilah yang diartikan sebaqai komponen fungsional dan di dalam dunia komputer dikenal dengan istilah sebagai berikut:

- INPUT UNIT

- alat pembaca/masukan data.

- CENTRAL PROCESSING UNIT

- alat pengolah utama.

- MEMORY / STORAGE UNIT

- alat penyimpan data.

- OUTPUT UNIT

- alat pengeluar hasil olahan.

a. Unit Masukan ( Input Unit )

Unit masukan atau Input Unit, merupakan suatu alat yang memungkinkan seseorang dapat berkomunikasi dengan komputer. Dengan alat ini semua data/informasi dimasukkan untuk dapat diolah oleh kamputer. Alat ini sering juga disebut sebagai input device. Contoh dari alat ini antara lain: keyboard, mouse, disk drive (penggerak disket).

b. Unit Pengolah Utama ( Central Processing Unit / CPU )

CPU merupakan "otak", yang menjadi bagian utama dari sebuah sistem komputer. Tugas utama' dari CPU adalah mengontrol keseluruhan sistem komputer, serta melaksanakan semua proses penghitungan dan loglka. Bagian utama dari CPU in2 adalah: 
1). Unit Aritmatika dan Logika ( Arithmetic Logical Unit / ALU )

Unit ini berfungsi untuk melakukan semua pekerjaan yang berhubungan dengan:

- proses aritmatika (perhitungan) dari data,

- operasi logika dari data,

- pemindahan data,

- pengqabungan data,

- dll, yang berhubungan dengan perlakuan terhadap data sesuai dengan prosedur dan instruksi yang diberikan.

2). Unit Pengendali ( Control Unit )

Sesuai dengan namanya, unit ini berfungsi mengatur, dan menqarahkan semua perangkat dalam sistem selama proses pengolahan data berlangsung. Jadi tugas dari unit ini adalah:

- Mengawasi bekerjanya peralatan input dan output.

- Mengambil dan mengirim data atau informasi dari storage unit.

- Mengendalikan arus atau lalu lintas data antara storage dan arithmatic unit selama proses pengolahan berlangsung.

- Mengatur pengolahan data secara fisik/mekanis.

c. Unit Penyimpan ( Memory / Storage Unit )

Unit ini mirip dengan suatu almari penyimpan berkas, dimana semua data disimpan secara sistematis menurut'pola tertentu, dan diberi indeks. Dengan card demikian data tersebut akan dapat secara cepat dipanggil 'kembali atau digunakan. Semua data yang akan digunakan atau diolah oleh komputer harus dimasukkan dulu ke memori ini.

Unit memori/storage komputer terdiri atas dua bahagian, yaitu Memori Utama yang berada di dalam dan bagian dari CPU sehingga dinamakan juga dengan Internal Plemory serta Memori Tambahan (External Hemor-y) yang terletak diluar CPU. Disamping ini adakalanya diperlukan memori lain sebagai memori bantu (Auxiliary Storage), 


\section{1). Memori Utama ( Internal Storage 1 )}

Berfungsi sebagai penampung data dan program yang akan diproses.

Internal storage ini terdiri atas dua bahagian utama, yaitu:

\section{- ROM ( Read Only Memory )}

Merupakan storage yang menyimpan program pbrmanen, dan tidak tergantung pada hidup atau matinya arus listrik. Program ini dapat dibaca dan diproses namun tidak dapat dirobah atau dihapus.

- RAM ( Random Acces Memory )

Bertugas untuk menampung semua informasi dari input unit yang akan diproses, serta semua informasi yang sudah selesai diolah oleh unit aritmatik dan logik.

\section{2). Memori Tambahan ( External Storage )}

Eagian ini merupakan unit tambahan yang terletak diluar mernori utama. Bagian ini dapat digolongkan kepada memori permanen, dimana data dapat disimpan dalam waktu relatif lama.

Contoh dari unit ini antara lain; Harddisk, diskkete, dan magnetic tape.

3). Memori Bantu ( Auxiliary Storage )

Unit memmori ini bertugas memban tu internal storage ( main storage / memori utama 1 dalam menampung data/informasi hasil pengolahan.

\section{d. Unit Keluaran ( Output Unit 1 )}

Output unit atau sering juga diistilahkan dengan Output device, adalah suatu alat yang diperlukan untuk menyimpan dan mencetak hasil pengolahan yang dilakukan oleh CPU berdasarkan perintah/program yang diberikan.

Istilah Output ini biasanya digunakan untuk dua tujuan, pertama istilah 
Output yanq mengacu pada data hasil pengolahan. Kedua Output device, yaitu perangkat keras yang akan mencetak atau menampilkan hasil penqolahan tersebut. Contohnya adalah: printer, plotter, Manitor dan External Storage.

\section{Perangkat Lunak ( Software )}

Software atau Perangkat Lunak adalah kumpulan perintah atau instruksi program yang mengarahkan operasi Hardware. Software ini dapat dibagi menjadi dua kategori, yaitu:

\section{a. Program Sistem ( System Software )}

Program Sistem atau System Software adalah suatu program kumpulan perintah yang memberikan bermacam -fasilitas kepada pemakai agar dapat menggunakan suatu sistem komputer.

\section{1). Sistem Operasi ( Operating System )}

Sistem Operasi atau Operating System merupakan sekelompok program yang mengendalikan dan me- . maksimumkan jalannya sistem komputer, disamping sebagai penghubung sistem pengkodean antara si pemakai dan perangkat komputer. Sistem operasi akan mengatur lalu lintas data dalam komputer, dan akan mengatur bagaimana komputer menggunakan atau melaksanakan semua instruksi dan program yang diberikan.

Sistem operasi ini banyak sekali macamnya, mulai dari yang digunakan pada personal computer (PC) sampai dengan sistem operasi yang digunakan pada komputer-komputer besar atau main frame, Saat ini terdapat banyak sekali macam sistem operasi. Semua sistem operasi tersebut pada dasarnya mempunyai fungsi utama yang sama; sebagai pengendali sistem dan penghubung antara manusia dan komputer. Diantara sistem operasi yang sekarang terdapat dipasaran adalah:

- DOS (Disk Operating System),

- TOS (Tape Operating System),

- BPS (Basic Programming Support), 
- EXEX -8,

- CP/M-86, dan

- UNIX, yang terdiri atas tiga versi yaitu: Xenix, PC/IX dan Venix.

Untuk jenis Komputer Pribadi (PC), DOS merupakan sistem operasi yang banyak dipakai, baik berupa IBM-DOS atau PC-DOS maupun MS-DOS.

\section{2). Compiler}

Berfungsi untuk menterjemahkan instruksi yang ditulis dalam bahasa tingkat tinggi (high level) kedalam bahasa tingkat rendah (low.level), yang dapat dimengerti oleh mesin komputer. Set.iap jenis dan versi bahasa tingkat tinggi mempunyai compilernya masing-masing .

b. Program Aplikasi ( Applicati Software )

Program Oplikasi atau Application Software merupakan jenis program yang dibuat untuk penggunaan tertentu. Program ini banyak sekali macamnya, dan dapat dibagi atas:

1). Program Paket ( Package Software )

Program Paket, adalah program aplikasi untuk menyelesaikan masalah yang bersifat umum, dengan fleksibilitas yang tinggi.

Melihat kepada sifat dan kegunaannya, maka program ini dapat dikelompokkan antara lain atas:

\section{a). Word Processor ( Pengolah Teks 1 )}

Program ini digunakan untuk menulis surat, naskah atau membuat buku dan sebagainya. Jenisnya seperti : Wordstar, Microsof $\mathrm{t}$ Word, ChiWriter, Mord Perfect dl1,

b). Database Management ( Manajemen Basis Data )

program yang berfungsi sebagai bank data dimana data tcrsebut dapat dimanfaatkan secara sistematis. Misalnya: dBase, FoxBase, mase dan lain-lain. 
C) . Spreadsheet ( Lembaran Kerja )

Merupakan lembaran kerja elektronik, dimana biasanya digunakan untuk proses-proses penanganan data yang berorientasi pada tabel-tabel dan perhitungannya. Misalnya: Lotus 123, Symphani, Multiplan, Quattru, dsb.

d). CAD/CAM, CAE

Digunakan sebagai alat bantu dalam proses disain suatu konstruksi teknik, mulai dari disain awal, penghitungan, gambar sampai kepada proses manuf akturnya. Umpamanya: AutoCAD, Mi c ruCAMP1, ATSupervision, Eagle, EesignCAD, d 11.

e) . Desktop Publishing

Program ini biasanya digunakan untuk merancang tata letak / lay-out dari suatu naskah yang akan dicetak. Sepintas seperti gabungan antara word processor, spreadsheet dan CAD. Contohnya: Ventura, Microsoft Mindows, dl 1.

f). Statistic ( Statistik )

Program-program j enis ini khusus digunakan terutama oleh mereka yang bergerak dibidang penelitian, evaluasi dan pengukuran sebagai alat bantu dalam menganalisa data. Con tohnya : Micrustat, SPSS, SAS dll.

g). Game ( Permainan )

Program, ini pada 'dasarnya hanya merupakan program hiburan dengan bermacam-macam jenis permainan, seperti: igger, Chess, SpaceGun dll.

c. Bahasa Program ( Programming Language )

Bahasa Program adalah bahasa yang digunakan untuk periuliran penulisan program-.. Bahasa ini terbagi atas 2 tingkatan, yaitu:

1). Bahasa Tingkat Rendah ( LOW Level Language )

Merupakan bahasa komputer yang berorientasi kepada perangkat komputer itu sendiri. Bahasa ini merupakan rentetan kode binari yang dapat langsung dibaca oleh mesin. Karena itu bahasa ini sering juga dinamakan dengan bahasa mesin. 


\section{2). Bahasa Tingkat Tinggi ( High Level Language )}

Bahasa tingkat tinggi merupakan bahasa program yang ,lebih komunikati'f dibanding bahasa tingkat rendah. Pernyataanpernyataannya relatif mirip / mendekati pernyataan dalam bahasa Inggeris. Namun. demikian tidak berarti sama dengan bahasa Inggeris. Disamping itu, program dalam bahasa tingkat tinggi ini pada umumnya kompatibel untuk beberapa jenis komputer. Atau mungkin hanya membutuhkan sedikit modifikasi said jika dilaksanakan pada komputer dari ienis .atau versi yang berbeda. Program yang ditulis dalam bahasa tingkat tinggi ini tidak langsung dapat dimengerti ,oleh komputer, tapi harus diterjemahkan dulu oleh compiler. Oleh compiler program tersebut diubahke dalam bahasa mesin yang dapat dimengerti komputer. Karena compiler menterjemahkan -ke dalam bahasa yang dapat dimengerti oleh mesin, maka untuk jenis bahasa program yang samapun mempunyai compiler yang berbeda sesuai dengan ienis mesinnya.

Sekarang ini mulai populer dan dipakai secara luas suatu jenis bahasa yang sebenarnya masih tergolong bahasa tingkat tinggi tapi dengan orientasi yang sama sekali berbeda. Kalau selama ini bahasa pemrograman berorientasi kepada prosedur penyelesaiannya, maka pada bahasa jenis ini orientasinya adalah objek dari program itu sendiri. Perbedaan yang demikian besar dan kemampuan yang dapat dilakukan dengan bahasa tersebut membuat bahasa kelompok ini populer untuk merancang program yang demikian "cerdasnya", sehingga sering dijuluki dengan "kecerdasan buatan" (artificial inteligence). Yang termasuk dalam kategori bahasa jenis ini antara lain adalah: Prolog dan LISP dengan berbagai versinya. 